\title{
Treatment on Hold
}

National Cancer Institute

\section{Source}

National Cancer Institute. Treatment on Hold. NCI Thesaurus. Code C106470.

A treatment is suspended. 